\title{
REFERENCES
}

1. Foster Moore.-Roy. Lond. Ophthal. Hosp. Rep., Vol. XIX, p. 411, 1914.

- Brit. Jl. of Ophthal., Vol. I, p. 26, 1917.

Trans. Ophthal. Soc. U K., Vol. XLVI, p. 120,1926.

Usher.-Trans. Ophthal. Soc. U.K., Vol. XLVI, p. 131, 1926.

Fuchs, E-Arch. f. Ophthal., Vol. XCIV, p. 43, 1917.

Fuchs, A.-Atlas of Histopathology, Vol. I, Plate 44, No. 3.

Magitot.-Ann. d'Ocul., p. 93, 1916.

Wolfrum.-Arch.f. Ophthal., Vol. LXXI, p. 278, 1909.

. Dimmer.-Der Augenspiegel.

10. Segalowitz.-Ophthal. Klinik, Vol. X, p. 225.

\section{EXOPHTHALMOS AND MIXED ASTIGMATISM CAUSED BY LARGE ETHMOID MUCOCELE}

BY

\author{
E. A. Seale, M.D. \\ Grahamstown, S. Africa.
}

Patient, a man aged 20 years, consulted me on February 15, 1928 , for a swelling about his left eye. He stated it began about four years previously and had gradually increased to its present size. Headaches were frequent and severe-the pain going through to back of head, and vision was affected. Some epiphora was present. There was a trifling redness over the swelling which occupied the inner orbital angle. On palpation it felt hard and firm; pressure gave a crackling which was both felt and heard. About its centre was a rather sharp, irregular-edged gap. Some oedema of the upper lid was noticeable. Proptosis was very marked. Forwards the eye extended $13 \mathrm{~mm}$., outwards $10 \mathrm{~mm}$., and downwards $5 \mathrm{~mm}$.

A history of severe influenza in the 1918 epidemic was given with several lighter subsequent attacks. On questioning as to injury he said that nine months previously he had a severe blow on the inner side of the left orbit through his head falling forward on to a tap, when recovering from gas in a dentist's chair. A bad " black eye" followed. About three months after this when blowing his nose a considerable quantity of thin yellowish fluid came away.

$\mathrm{R} . \mathrm{V} .=6 / 6$.

L.V. $=6 / 36$, with correction $=6 / 12$.

Muscles. Maddox rod, exophoria $2^{\circ}$. Hyperphoria $2^{\circ}$.

Fundus normal.

$$
\text { Maddox wing, exophoria } 15^{\circ} \text {. Hyperphoria } 0.5^{\circ} \text {. }
$$

Operation was advised, as condition was diagnosed as an ethmoidal mucocele.

A few days later the case was shown at a B.M.A. clinical meeting. The photograph here reproduced was taken March 1, 1928. 
(Fig. 1.) Circumstances prevented the patient having the operation then, and I did not see him again till the following May 14. Condition then was much the same. Vision was a little poorer.

L.V. $=6 / 36$ barely. With correction $=6 / 12$.

He noticed that gentle finger pressure above in 11 o'clock position gave better vision. On testing this I found his statement true. and was able to improve vision to $6 / 12$ without glasses.

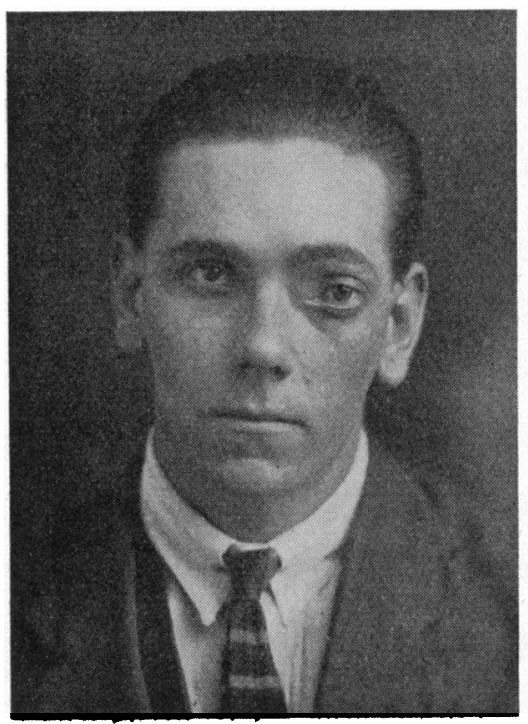

Fig. 1.

I sent him to Mr. R. M. Leith, Port Elizabeth, who operated on May 22, and wrote to me that " it was a very large ethmoidal mucocele extending to the back of the orbit and floor of frontal sinus. The inner wall of the orbit was entirely absorbed ... the displacement should right itself and it will be interesting to see if the vision improves.'

June 25, 1928. Appearance much improved by operation: proptosis less.

L.V. $=6 / 18$. With correction $=6 / 9$.

August 13. Improving, but still some exophthalmos.

R.V. $=6 / 4.5$

L.V. $=6 / 18$. With correction $=6 / 9$.

P.D. =6.2. Ord.

April 15, 1929. Very well. Glasses comfortable. No headaches. Left eye still a trifle anterior to right in position.

L.V. $=6 / 18$ improved to $6 / 5 \frac{\text { cum }-0.50 \mathrm{D} . \text { Sph. }}{\text { c. }+2.25 \text { Cyl. axis } 30^{\circ} \text { in. }}$ 
Hyperphoria $1^{\circ}$. Exophoria $1^{\circ}$ (Maddox rod). $2^{\circ}$. $\quad, \quad 14^{\circ}$ (Maddox wing).

Fundus, normal. Photograph taken then reproduced. (Fig. 2.) Hyperphoria causes no discomfort : rides motor cycle.

August 15,1929 . The cylinder was reduced to $+1.75 \mathrm{D}$. axis $30^{\circ}$ in.

It is probable the diminished visual acuity was due to a certain

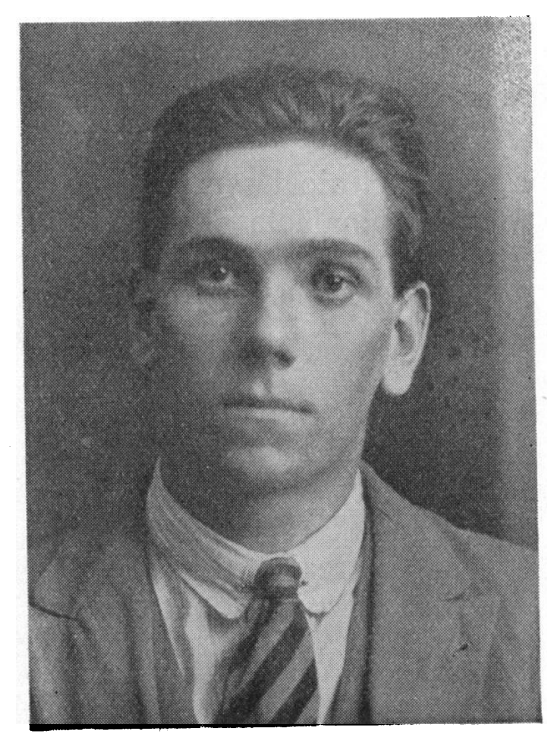

FIG. 2.

amount of retro-bulbar neuritis from distended ethmoid cells pressing on the optic nerve.

I am fortunate in having a record of the vision taken in April, 1922 , aged $14 \frac{1}{2}$ years. He then came complaining of headaches and soreness of eyes. His vision was $6 / 9$ in each eye with $+1.0 \mathrm{D} . \mathrm{Sph}$. $+0.25 \mathrm{D}$.Cyl. axis horizontal in R., and +1.0D.Sph. +0.5D.Cyl., axis horizontal, in left.

The diminution of his hypermetropia between 14 and 20 years is interesting and unusual. His previous correction was now much too strong. It does not accord with Duke-Elder's views: " In children hypermetropia tends normally to diminish with growth and consequently the refraction usually approaches emmetropia gradually until adolescence is passed."* My patient's hypermetropia continued to lessen much beyond that period.

*"The Practice of Refraction," Duke-Elder, p. 93. 